\title{
Running Characterization of Electric Bus Powered by Mn Type Lithium Ion Battery
}

\author{
Hiroshi Matsuo ${ }^{1}$, Takayuki Kodera ${ }^{2}$, and Takashi Ogihara ${ }^{3}$ \\ ${ }^{1}$ Graduate School of Material Science \& Engineering, University of Fukui, matsuo@kkf.biglobe.ne.jp \\ ${ }^{2}$ Graduate School of Material Science \& Engineering, University of Fukui, t-kodera@icpc00.ccns.u-fukui.ac.jp \\ ${ }^{3}$ Graduate School of Material Science \& Engineering, University of Fukui, ogihara@matse.u-fukui.ac.jp
}

\begin{abstract}
Electric bus powered by Mn-type lithium ion battery module with $53 \mathrm{kWh}$ was developed. The running test was examined in the local city in Japan. The relation between running time and voltage, current and electric power consumption were investigated. The electric bus was run when the lithium ion battery module was discharged between 380 and $270 \mathrm{~V}$. On one charge, it was also found from the running test that the railcar could run for 74 $\mathrm{km}$. The running performance of electric bus was equivalent to the diesel bus. It was found that the electric bus powered by lithium ion battery was effective for the replace of diesel type bus.
\end{abstract}

\section{Keywords}

electric vehicle, lithium ion battery, energy saving, bus, carbon dioxide discharge

\section{INTRODUCTION}

Recently, as a measure for global warming, the use of new energy systems, such rechargeable batteries, fuel cells, solar power and wind power, has been expected to reduce the discharge of carbon dioxide. $24 \%$ of total energy consumption and $20 \%$ of carbon dioxide discharge re attributed to the transportation section. Therefore, it is important to develop the electric vehicles (EVs) and hybrid electric vehicles (HEVs) which have higher energy-saving effect and lower discharge of carbon dioxide than gasoline car [Lindly et al., 2002; Åhman et al., 2006] . Thus, the rechargeable batteries such as $\mathrm{Pb}$ [Moseley et al., 1999] and $\mathrm{NiH}$ [Gifford et al., 1999] batteries have been used for EVs and HEVs. From the viewpoint of performance such as weight, energy and power density, lithium ion battery [Hyung et al., 1999; Horiba et al., 2003] is expected to be the candidate battery for EVs and HEVs. On the other hand, the diesel type bus is only used in the public transport. Therefore, it is effective to convert the diesel bus to the electric bus for improving reduction effect of the carbon dioxide. So far, the hybrid type bus powered by the battery such as fuel cell [Folkesson et al., 2003], Pb battery [Nakayama et al., 2003], capacitor [Sasaki et al., 2002] has been developed. However, the running characterization of pure electric bus powered only by the large Mn type lithium ion battery has been seldom reported. We have been reported the performance of Mn-type lithium ion battery for the running of electric bus [Motohira et al, 2007]. In this work, the pure electric bus was devel- oped on the assumption of the utilization as welcome and farewell of the company and circulation of the community zone. In this paper, the running performance of electric bus powered by Mn-type lithium ion battery was described. In addition, the effect of energy-saving and reduction of carbon dioxide discharge for the running of electric bus were also described.

\section{EXPERIMENT}

\subsection{Lithium ion battery}

Spinel type lithium manganate cathode material has been used as a Mn type lithium ion battery for EVs. Lithium ion battery with higher safety and longer are required for the public transportation such as a bus. However, lithium manganate has a poor life cycle due to the dissolution of $\mathrm{Mn}$ ion at the temperature more than $50{ }^{\circ} \mathrm{C}$. It was known that the addition of foreign metal ion such as $\mathrm{Mg}^{2+}, \mathrm{Cr}^{3+}$ and $\mathrm{Al}^{3+}$ led to the long life cycle of lithium manganate cathode material. In this work, $5 \mathrm{~mol} \%$ of $\mathrm{Al}^{3+}$ ion was doped to lithium manganate to improve the above problem. $\mathrm{Al}^{3+}$ ion doped lithium manganate powders $\left(\mathrm{LiAl}_{0.05} \mathrm{Mn}_{1.95} \mathrm{O}_{4}\right.$, LAMP) were used as cathode materials. LAMP [Mukoyama et al., 2006] was largely produced by spray pyrolysis apparatus (Chugairo Co., Ltd). The rechargeable capacity of LAMP was $120 \mathrm{mAh} / \mathrm{g}$ at 1 C. The rechargeable capacity of LAMP maintained 80 $\%$ of initial capacity at $1 \mathrm{C}$ after 3000 cycle. Laminate type cell which was specially produced using LAMP with high energy density and long life cycle by the battery manufacturer (Enax Co., Ltd.) was used as a lithium ion cell.

The cathode was prepared using $88 \mathrm{wt} \%$ LAMP, $6 \mathrm{wt} \%$ acetylene black and $6 \mathrm{wt} \%$ fluorine resin. They were homogeneously mixed in $N$-methyl-2- 
pyrrolidone to obtain slurry and then slurry coated on aluminium foil using doctor blade. A mixture of hard carbon and graphite (1:1 volume ratio) was used as the anode. A porous polypropylene sheet was used as the separator. As the electrolyte, $1 \mathrm{~mol} / \mathrm{dm}^{3} \mathrm{LiPF}_{6}$ in ethylene carbonate / 1,2-dimethoxyethane (EC : DME $=1: 1$ in volume ratio) was used. Table 1 shows the specification of lithium ion cell and lithium ion battery module. Lithium ion cell $(170 \mathrm{~mm} \times 160 \mathrm{~mm} \times 5 \mathrm{~mm}$, 8.6 Ah, 3.8 V, $250 \mathrm{~g}$ ) was assembled in a globe box under an argon atmosphere. The energy density and power density of lithium ion cell was $120 \mathrm{Wh} / \mathrm{kg}$ and $2920 \mathrm{~W} / \mathrm{kg}$, respectively. Lithium ion battery $(200 \mathrm{~mm}$ $\times 150 \mathrm{~mm} \times 700 \mathrm{~mm}, 155 \mathrm{Ah}, 57 \mathrm{~V}, 80 \mathrm{~kg}$ ) consisting of 270 lithium ion cells, in which 15 cells connected in 18 series were connected in parallel. 270 lithium ion cells were set in the aluminium case with a cooling fan. The heat generated in the rechargeable process was given off by cooling fan. Battery Management
Systems (BMS) were also installed in each series cell as a safety measure to avoid overcharging, excessive discharging and overheating. Table 2 shows the specification of lithium ion battery module. Six lithium ion batteries were connected in series to obtain $53 \mathrm{kWh}$ (155 Ah, $348 \mathrm{~V})$ of lithium ion battery module.

\subsection{Electric bus}

Figure 1 shows a photograph of electric bus with lithium ion battery module. It was mounted on the rear of bus (Mitsubishi Rosa, 4,120 kg, 28 passengers). The diesel engine, the fuel tank, and the transmission of a conventional bus were replaced with an electric motor (DC motor, 120 kW Drive System, Enova Co., Ltd.), and an inverter.

2.3 Evaluation of lithium ion battery and electric bus The basic running performances of electric bus such as maximum speed, running distance, and accelerating

Table 1 Specification of lithium ion cell and lithium ion battery

Lithium ion cell

\begin{tabular}{l|l}
\hline Item & Specification \\
\hline Average output voltage & $3.8 \mathrm{~V}$ \\
Operation voltage range & $3-4.3 \mathrm{~V}$ \\
Capacity & $8.6 \mathrm{Ah}$ \\
Operation temperature & $-10-45^{\circ} \mathrm{C}$ \\
Dimensions & $170 \mathrm{~mm} \times 160 \mathrm{~mm} \times 5.3 \mathrm{~mm}$ \\
Weight & $233 \mathrm{~g}$ \\
Power density & $2920 \mathrm{~W} / \mathrm{kg}$ \\
Energy density & $120 \mathrm{Wh} / \mathrm{kg}$ \\
\hline
\end{tabular}

Lithium ion battery

\begin{tabular}{l|l}
\hline Item & Specification \\
\hline Average output voltage & $57 \mathrm{~V}$ \\
Operation voltage range & $45-64.5 \mathrm{~V}$ \\
Capacity & $155 \mathrm{Ah}$ \\
Electric energy & $8.8 \mathrm{kWh}$ \\
Operation temperature $\left({ }^{\circ} \mathrm{C}\right)$ & $-10-45^{\circ} \mathrm{C}$ \\
Dimensions & $240 \mathrm{~mm} \times 300 \mathrm{~mm} \times 1000 \mathrm{~mm}$ \\
Weight & $80 \mathrm{~kg}$ \\
Component of lithium ion cell & 18 series and 15 parallels \\
\hline
\end{tabular}

Table 2 Specification of lithium ion battery module

\begin{tabular}{l|l}
\hline Item & Specification \\
\hline Average output voltage & $348 \mathrm{~V}$ \\
Operation voltage range & $270-387$ \\
Capacity & $155 \mathrm{Ah}$ \\
Electric energy & $53 \mathrm{kWh}$ \\
Dimensions & $1440 \mathrm{~mm} \times 300 \mathrm{~mm} \times 1000 \mathrm{~mm}$ \\
Weight & $480 \mathrm{~kg}$ \\
Components of lithium ion battery & 6 series \\
\hline
\end{tabular}




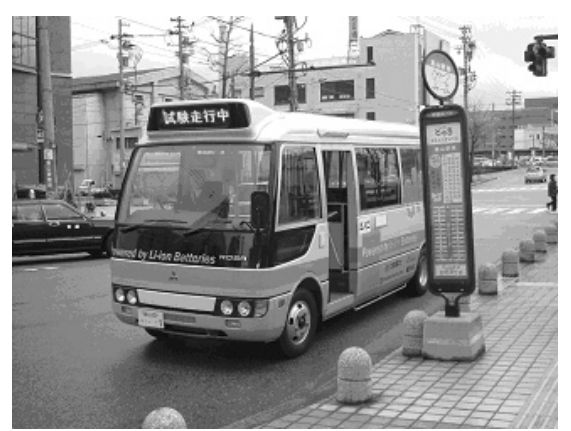

(a) Electric bus

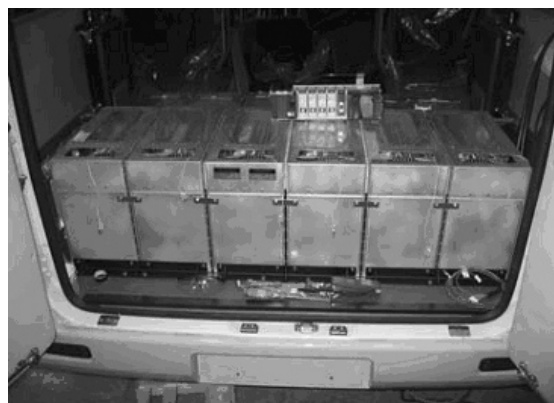

(b) Lithium ion battery module

Fig. 1 Electric bus and lithium ion battery module used in this work

power were examined at Shirosato Test Centre (Japan Automobile Research Institute). The demonstration of running was also examined in the public road at Toyama City in Japan. Each change of voltage, current and temperature in the running was collected in personal computer through the data logger set in the centre of submodule. The charge test of lithium ion battery module was also carried out by quick battery charger apparatus after the running, and then the charge performance of lithium ion battery module was examined.

\section{RESULTS AND DISCUSSIONS}

The acceleration of electric bus powered by lithium ion battery was examined, and then one example of

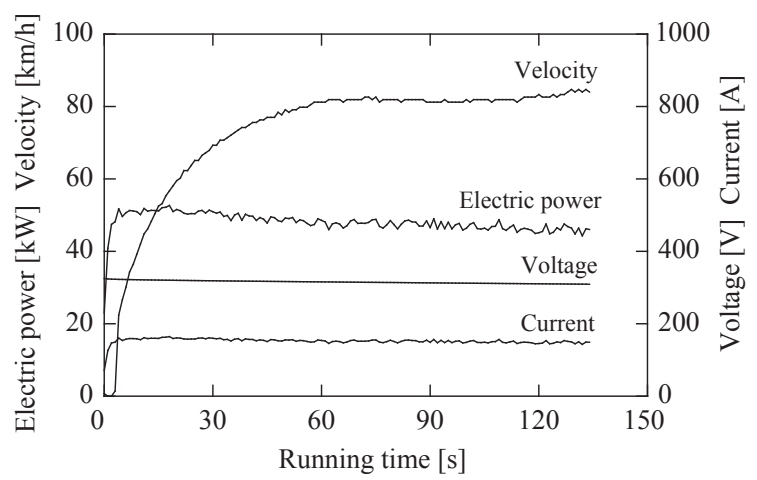

Fig. 2 An example of the relation between the running time and the velocity, the electric power, the voltage, the current the performance was shown. The electric bus was accelerated up $130 \mathrm{~s}$. Figure 2 shows an example of the relation between the running time and the velocity, the electric power, the voltage, the current. The current reached $155 \mathrm{~A}$ in $6 \mathrm{~s}$ and then the electric power reached $50 \mathrm{~kW}$. The electric bus reached $30 \mathrm{~km} / \mathrm{h}$ in 6 $\mathrm{s}$ and $84 \mathrm{~km} / \mathrm{h}$ after $130 \mathrm{~s}$. The battery voltage changed from $324 \mathrm{~V}$ to $309 \mathrm{~V}$ for $130 \mathrm{~s}$. The consumption of electric power was $4 \mathrm{~kW}$ for $130 \mathrm{~s}$. The electric bus could run for $2.4 \mathrm{~km}$ for $130 \mathrm{~s}$ and then the mileage of it was $0.6 \mathrm{~km} / \mathrm{kW}$ for $130 \mathrm{~s}$.

Figure 3 shows an example of the relation between the velocity and the current, the electric power. The current rate and electric power increased with increasing the speed. The max speed of $90 \mathrm{~km}$ also reached at $150 \mathrm{~A}$. This is correspondent to $1 \mathrm{C}$. The output of electric power was $51 \mathrm{~kW}$. This result suggests that the load of lithium ion battery is little for the acceleration of the electric bus.

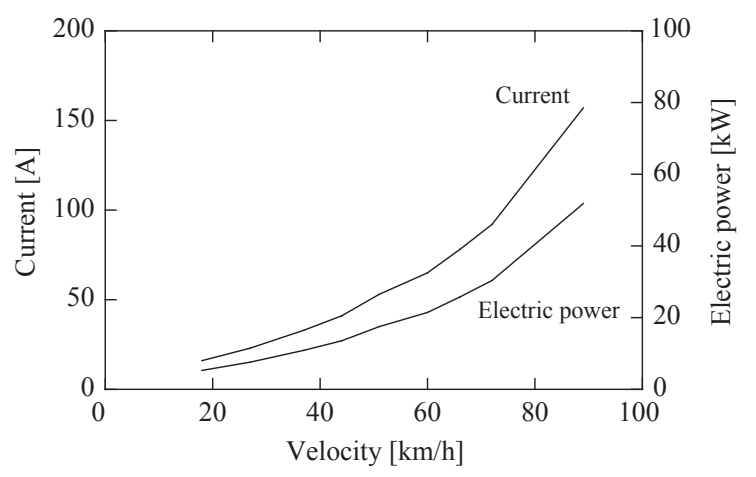

Fig. 3 An example of the relation between the velocity and the discharge rate, the electric power

The running test on the assumption of the utilization as welcome and farewell of the company was carried out in public road. The electric bus was charged up to $100 \%$ at $1 \mathrm{C}$. The running was carried out in early morning in the winter. The ambient temperature was $3{ }^{\circ} \mathrm{C}$. Figure 4 shows one example of the relation be-

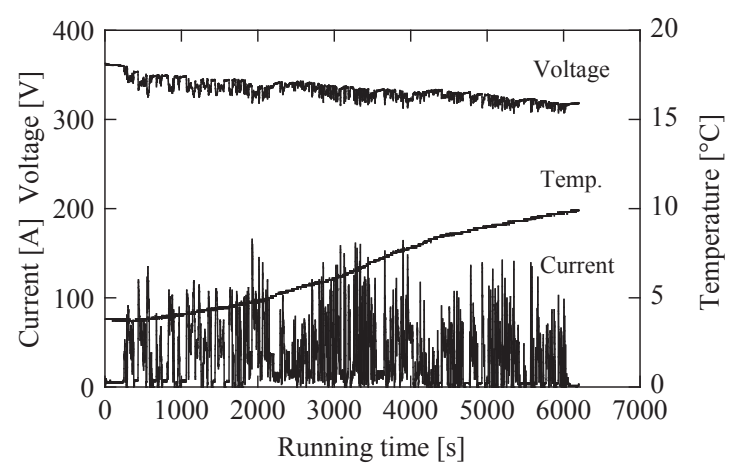

Fig. 4 An example of the relation between the running time, and the voltage, the current, the temperature 
tween the running time, and the voltage, the current, the temperature of lithium ion battery module. Thermosensor was inserted in the centre of the lithium ion battery, and then the temperature change was monitored. Lithium ion battery module discharged from $362 \mathrm{~V}$ to $318 \mathrm{~V}$ for $6200 \mathrm{~s}$. The current frequently flowed every acceleration and the max current was $150 \mathrm{~A}(1 \mathrm{C})$. The temperature increased to $10{ }^{\circ} \mathrm{C}$. This may be resulted in the ohmic loss and the polarization of lithium ion cell. It was found that the discharge of the lithium ion battery module was done even in midwinter, and also the temperature rise was little in spite of the frequent discharge.

Figure 5 shows an example of the relation between the running time and the velocity, the distance, the electric power consumption. The electric bus could run for 37 $\mathrm{km}$ for $6200 \mathrm{~s}$. The average and the maximum speed of electric bus were 20.3 and $51.1 \mathrm{~km} / \mathrm{h}$, respectively. The electric power consumption of lithium ion battery was $19.7 \mathrm{kWh}$. The electric mileage was $1.87 \mathrm{~km} /$ $\mathrm{kWh}$. Therefore, the fuel consumption became 19.89 $\mathrm{km} / \mathrm{L}$. This was calculated by using the equivalent to coefficient (3.6 MJ/kWh) and heat quantity of crude oil (38.7 MJ/L) which Ministry of Economy, Trade and Industry (METI) determined. On the other hand, the fuel consumption of diesel bus was $3.75 \mathrm{~km} / \mathrm{L}$. The fuel consumption of electric bus improved 5.3 times compared with that of diesel bus. We obtained the carbon dioxide emission of electric bus and diesel bus. The emission of carbon dioxide of electric bus was $9 \mathrm{~kg}-\mathrm{CO}_{2}$ (METI) for $37 \mathrm{~km}$ running. The carbon dioxide emission intensity of electricity was calculated as $0.457 \mathrm{~kg}-\mathrm{CO}_{2} / \mathrm{kWh}$ (METI). The emission of carbon dioxide of diesel bus was also $25.8 \mathrm{~kg}-\mathrm{CO}_{2}$. The carbon dioxide emission intensity of light oil was calculated as $2.62 \mathrm{~kg}-\mathrm{CO}_{2} / \mathrm{L}$. The emission of carbon dioxide of electric bus improved 2.8 times compared with that of diesel bus. It is effective to convert the diesel engine to the motor system powered by lithium

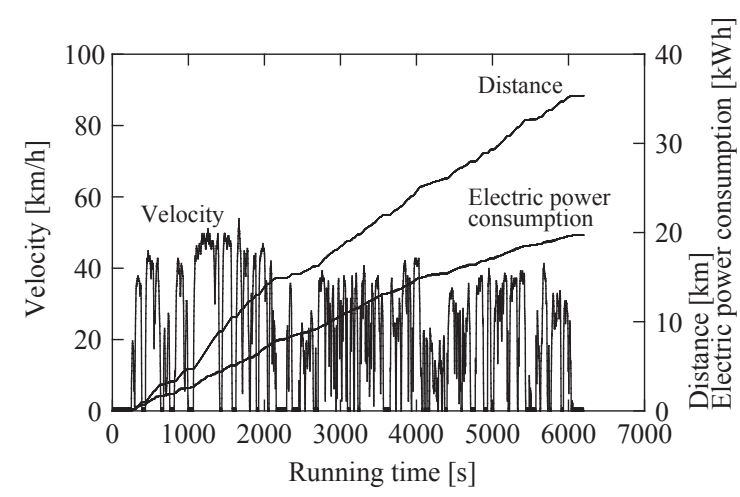

Fig. 5 An example of the relation between the running time and the velocity, the distance, the electric power consumption ion battery for the energy saving and reduction of carbon dioxide.

The running test on the assumption of circulation of the community zone was also carried out in public road at Toyama-city. The electric bus was charged up to $100 \%$ at $1 \mathrm{C}$ before the running. The running was carried out at afternoon in the summer. The ambient temperature was $30^{\circ} \mathrm{C}$. Figure 6 shows an example of the relation between the running time and the voltage, the current, the electric power consumption of lithium ion battery. Lithium ion battery module discharged from $370 \mathrm{~V}$ to $280 \mathrm{~V}$ for $9700 \mathrm{~s}$. The current frequently flowed every acceleration and the max current was 150 A (1 C). The consumed electric power was 36.1 $\mathrm{kWh}$ after the running. Figure 7 shows an example of relation between the running time and the velocity, distance of electric bus. The average speed and $\max$ speed of electric bus was $38 \mathrm{~km} / \mathrm{h}$ and $64 \mathrm{~km} / \mathrm{h}$, respectively. The electric bus could run for $74 \mathrm{~km}$ by repeating the acceleration and deceleration. The electric mileage of electric bus was $2.04 \mathrm{kWh} / \mathrm{km}$.

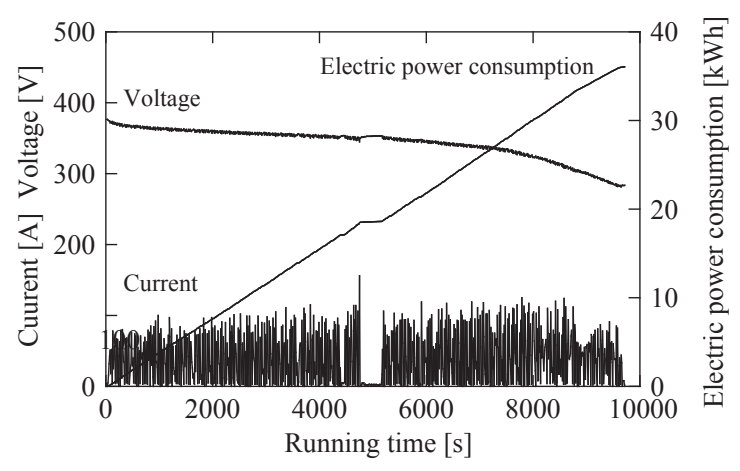

Fig. 6 An example of the relation between the running time and the voltage, the current, electric power consumption

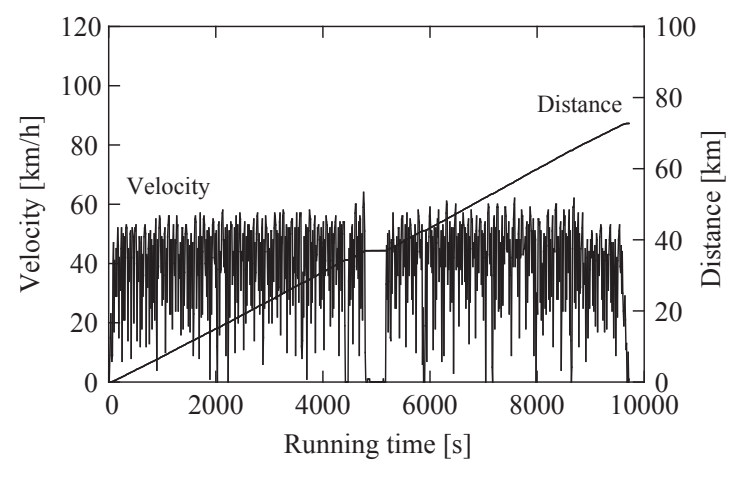

Fig. 7 An example of the relation between the running time and the velocity, the distance

The charge test of lithium ion battery module was carried out after the running. Lithium ion battery module which $36.1 \mathrm{kWh}$ of electric power was consumed after the running was charged at $1 \mathrm{C}(150 \mathrm{~A})$ by using the 


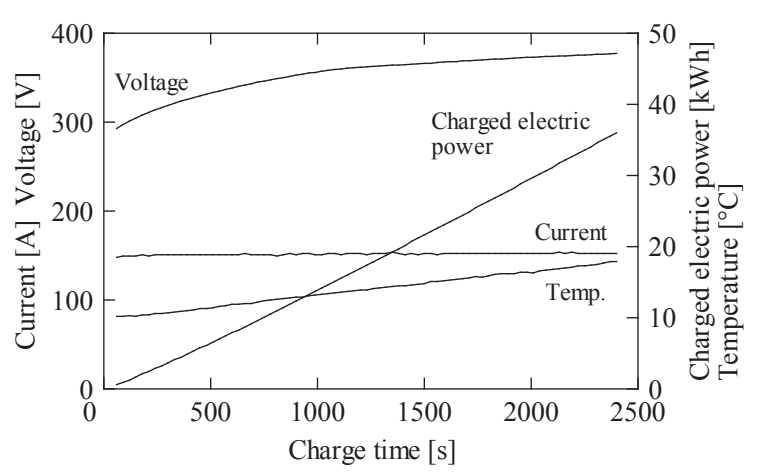

Fig. 8 An example of the relation between the charge time and the current, the voltage, the temperature, the charged electric power

quick battery charger apparatus. Figure 8 shows an example of the relation between the charge time and the voltage, the current, the temperature, the charged electric power of the lithium ion battery module. The voltage of charge ranged from $280 \mathrm{~V}$ to $380 \mathrm{~V}$. 36.1 $\mathrm{kWh}$ of electric power was charged for $2400 \mathrm{~s}$ at $1 \mathrm{C}$. The temperature of lithium ion battery increased from $10{ }^{\circ} \mathrm{C}$ to $18{ }^{\circ} \mathrm{C}$ when the electric power of lithium ion battery module was reached to $36 \mathrm{kWh}$ for $2400 \mathrm{~s}$. The abnormal temperature rise of lithium ion battery module was not occurred during the charge. 200 times of charge test was carried out under the same condition. The capacity of lithium ion battery module was maintained $90 \%$ of initial capacity after 200 times.

It was found that the degradation of lithium ion battery module was very slight. The storage of lithium ion battery module was also examined. After the running test for one year, lithium ion battery module was stored at room temperature without the charge for three years. The capacity of lithium ion battery module that three years passed was measured. The capacity of lithium ion battery module decreased to $70 \%$ of the initial capacity due to the self-discharge of lithium ion cell. The performance of storage is seemed to be excellent because the capacity loss of lithium ion battery module is $30 \%$ for three years.

\section{CONCLUSION}

$53 \mathrm{kWh}$ of Mn type lithium ion battery module was developed for the running of electric bus. Lithium ion battery module consisted of 6 submodules in which laminate type lithium ion cells were connected in 15 series and 18 parallel. The running test of electric bus was carried out at public road at Toyama-city in Japan. The results were obtained as follows;

(1) The speed of electric bus increased with increasing the current. The max speed of electric bus was $90 \mathrm{~km} / \mathrm{h}$ at discharge of $150 \mathrm{~A}$ (1 C) when 120 $\mathrm{kW}$ of ac electric motor was used.
(2) The electric bur could run in winter. The increase of temperature was $7^{\circ} \mathrm{C}$. The consumed electric power of lithium ion battery was $19.7 \mathrm{kWh}$ for the running of $37 \mathrm{~km}$.

(3) The electric bus could run for $74 \mathrm{~km}$ when the lithium ion battery discharged from $380 \mathrm{~V}$ to 280 $\mathrm{V}$.

(4) The fuel consumption of bus improved about two times by converting from diesel engine to electric motor powered by lithium ion battery.

(5) The emission of carbon dioxide of electric bus improved about 2.8 times compared with that of diesel bus.

(6) The temperature rise of lithium ion battery module was slight at $1 \mathrm{C}$, and the $90 \%$ of initial capacity was maintained after 200 times.

\section{Acknowledgements}

The authors thank Hokuriku Electric Power Company, Tokyo R\&D, Mitsubishi Fuso Truck and Bus Corporation and KEC Corporation for the running and charge test of electric bus.

\section{References}

Åhman, M., Government policy and the development of electric vehicles in Japan, Energy Policy, Vol. 34, 433-443, 2006.

Gifford, P., J. Adams, D. Corrigan, and S. Venkatesan, Development of advanced nickel/metal hydride batteries for electric and hybrid vehicles, Journal of Power Sources, Vol. 80, 157-163, 1999.

Horiba, T., K. Hironaka, T. Matsumura, T. Kai, M. Koseki, and Y. Muranaka, Manganese-based lithium batteries for hybrid electric vehicle applications, Journal of Power Sources, Vol. 119-121, 893-896, 2003.

Hyung, Y. E., S. I. Moon, D. H. Yum, and S. K. Yun, Fabrication and evaluation of 100 Ah cylindrical lithium ion battery for electric vehicle applications, Journal of Power Sources, Vol. 81-82, 842-846, 1999.

Folkesson, A., C. Andersson, P. Alvfors, M. Alaküla, and L. Overgaard, Real life testing of a hybrid PEM fuel cell bus, Journal of Power Sources, Vol. 118, 349-357, 2003.

Lindly, J. K., and T. A. Haskew, Impact of electric vehicles on electric power generation and global environmental change, Advances in Environmental Research, Vol. 6, 291-302, 2002.

Moseley, P. T., and A. Cooper, Progress towards an advanced lead-acid battery for use in electric vehicles, Journal of Power Sources, Vol. 78, 245-250, 1999.

Motohira, S., T. Ogihara, K. Myojin, I. Mukoyama, T. 
Nakamura, H. Ozawa, H. Morino, N. Ohnuma, M. Uede, K. Fujii, T. Futakuchi, and T. Watanabe, Development of pure electric bus with Mn type li-ion battery, WEVA Journal, Vol. 1, 165-169, 2007.

Mukoyama, I., K. Myoujin, T. Ogihara, M. Uede, H. Ozawa, and K. Ozawa, Large-scale synthesis and electrochemical properties of $\mathrm{LiAl}_{\mathrm{X}} \mathrm{Mn}_{2-\mathrm{X}} \mathrm{O}_{4}$ powders by internal combustion type spray Pyrolysis apparatus using gas burner, Key Engineering Materials, Vol. 320, 251-254, 2006.

Nakayama, Y., E. Hojo, and T. Koike, Development of VRLA battery for hybrid bus, Journal of Power Sources, Vol. 124, 551-558, 2003.

Sasaki, M., S. Araki, T. Miyata, and T. Kawaji, Development of capacitor hybrid system for urban buses, JSAE Review, Vol. 23, 451-457, 2002.

(Received April 18, 2010; accepted May 31, 2010) 